\title{
Connective tissue spectrum abnormalities associated with spontaneous cerebrospinal fluid leaks: a prospective study
}

\author{
Eyal Reinstein ${ }^{\star 1}$, Mitchel Pariani ${ }^{1}$, Serguei Bannykh ${ }^{2}$, David L Rimoin ${ }^{*}, 1$ and Wouter I Schievink ${ }^{3}$
}

We aimed to assess the frequency of connective tissue abnormalities among patients with cerebrospinal fluid (CSF) leaks in a prospective study using a large cohort of patients. We enrolled a consecutive group of 50 patients, referred for consultation because of CSF leak. All patients have been carefully examined for the presence of connective tissue abnormalities, and based on findings, patients underwent genetic testing. Ancillary diagnostic studies included echocardiography, eye exam, and histopathological examinations of skin and dura biopsies in selected patients. We identified nine patients with heritable connective tissue disorders, including Marfan syndrome, Ehlers-Danlos syndrome and other unclassified forms. In seven patients, spontaneous CSF leak was the first noted manifestation of the genetic disorder. We conclude that spontaneous CSF leaks are associated with a spectrum of connective tissue abnormalities and may be the first noted clinical presentation of the genetic disorder. We propose that there is a clinical basis for considering spontaneous CSF leak as a clinical manifestation of heritable connective tissue disorders, and we suggest that patients with CSF leaks should be screened for connective tissue and vascular abnormalities.

European Journal of Human Genetics (2013) 21, 386-390; doi:10.1038/ejhg.2012.191; published online 29 August 2012

Keywords: hereditary disorders of connective tissue; spontaneous cerebrospinal fluid leak; positional headache screening

\section{INTRODUCTION}

Spontaneous cerebrospinal fluid (CSF) leak is an uncommon condition usually diagnosed in patients presenting with a positional orthostatic headache, following studies confirming low CSF pressure, and/or evidence of a CSF leak on Neuroimaging studies. ${ }^{1}$ Spontaneous CSF leaks are under-diagnosed and frequently misdiagnosed, because only the minority of patients undergo the appropriate evaluation. The exact underlying pathogenic mechanism is unknown and an excessive fragility of the spinal dura has been suggested as a cause. ${ }^{2}$ Hereditary disorders of connective tissue (HDCT) comprise a clinically and genetically heterogeneous group of disorders, characterized by generalized fragility of connective tissues. The prevalence of HDCT has been estimated at 1:5000; however, it may be higher, as it is likely that some individuals with milder clinical manifestations do not come to medical attention. ${ }^{3}$ Single-gene defects in genes involved in the regulation of connective tissue biology have been identified for some of the HDCT (such as in Marfan syndrome (OMIM\# 154700), many forms of Ehlers-Danlos syndrome (EDS), etc), but in most cases the diagnosis is established clinically. ${ }^{4,5}$ Several case reports and small studies, published in the neurosurgical literature, suggested a link between HDCT and spontaneous CSF leaks, but the precise prevalence is not clear. ${ }^{6-9}$ Here we report the clinical and molecular findings in a cohort of 50 patients with spontaneous CSF leaks. We propose that there is a broad clinical basis for considering spontaneous CSF leak as a clinical manifestation of HDCT, and that those patients with spontaneous CSF leaks should be screened for connective tissue and vascular abnormalities.

\section{MATERIALS AND METHODS}

We enrolled a consecutive group of 50 patients, aged 12-67, referred for consultation of a spontaneous spinal CSF leak from December 2009 to September 2011. All patients were diagnosed according to previously published diagnostic criteria for this condition that include clinical evaluation and imaging studies. ${ }^{1}$ Briefly, the diagnostic criteria consist of (a) orthostatic headache; (b) the presence of at least one of the following: low opening pressure, sustained improvement of symptoms after epidural blood patching, demonstration of an active spinal cerebrospinal fluid leak, cranial magnetic resonance imaging changes of intracranial hypotension; (c) no recent history of dural puncture; and (d) not attributable to another disorder. The subjects in this cohort have not been included in previous studies. Patients were provided with oral and written information detailing the study and asking for their participation at admission to the hospital and informed consent was obtained (CSMC IRB Protocols 0463 and 4232). Ancillary diagnostic testing, including genetic testing, echocardiography, eye exam, and histopathological examinations of skin and dura, were obtained in selected patients, on the basis of the findings on physical examination and medical history. All patients have been evaluated by a single medical geneticist according to the same protocol that included questions pertaining to the medical history, and clinical examination aimed on identifying skin, musculoskeletal, cardiovascular (by echocardiogram), cranio-facial and vision abnormalities. The evaluation protocol is depicted in Table 1.

\section{Skin and dura biopsies}

Skin and dura samples were collected in patients consented for the procedure, at the time of CSF leak repair. Freshly excised biopsies of the back skin and spinal dura were fixed, cut, and viewed with Jeol 100CX transmission electron microscope at $80 \mathrm{k}$. Digital images were collected and analyzed by an expert pathologist.

${ }^{1}$ Medical Genetics Institute, Cedars-Sinai Medical Center, Los Angeles, CA, USA; ${ }^{2}$ Department of Pathology, Cedars-Sinai Medical Center, Los Angeles, CA, USA; ${ }^{3}$ Department of Neurosurgery, Cedars-Sinai Medical Center, Los Angeles, CA, USA

Deceased.

*Correspondence: Dr E Reinstein, Medical Genetics Institute, Cedars-Sinai Medical Center, 8700 Beverly Blvd, Los Angeles, CA 90048 , USA. Tel: + 3104239904 . Fax: + 310423 2080; E-mail: reinstein.eyal@gmail.com

Received 27 March 2012; revised 10 July 2012; accepted 20 July 2012; published online 29 August 2012 
Table 1 Protocol for clinical evaluation of hereditary disorders of connective tissue in patients with CSF leaks

\begin{tabular}{|c|c|c|c|c|c|c|}
\hline $\begin{array}{l}\text { Demographic and } \\
\text { general }\end{array}$ & $\begin{array}{l}\text { Pregnancy, } \\
\text { developmental } \\
\text { and neonatal history }\end{array}$ & $\begin{array}{l}\text { Signs for skin } \\
\text { hyperextensibility } \\
\text { and fragility }\end{array}$ & $\begin{array}{l}\text { Joint hypermobility } \\
\text { and complications }\end{array}$ & $\begin{array}{l}\text { Cardiovascular } \\
\text { (history and echo } \\
\text { cardiography) }\end{array}$ & Craniofacial & Ophthalmologic \\
\hline Age and gender & $\begin{array}{l}\text { Delivery type, } \\
\text { presentation, } \\
\text { gestational age } \\
\text { (term; pre-term, } \\
\text { post term) }\end{array}$ & $\begin{array}{l}\text { Skin hyperextensibility/ } \\
\text { elasticity }\end{array}$ & Joint dislocations & $\begin{array}{l}\text { Aortic or other } \\
\text { arterial aneurysm, } \\
\text { dissection or rupture } \\
\text { (personal or family } \\
\text { history of) }\end{array}$ & $\begin{array}{l}\text { Dental history } \\
\text { crowding/braces }\end{array}$ & $\begin{array}{l}\text { Personal or } \\
\text { family } \\
\text { history of lens } \\
\text { dislocation }\end{array}$ \\
\hline $\begin{array}{l}\text { Ht/Wt } \\
\text { Body habitus } \\
\text { (marfanoid, slender, } \\
\text { etc) }\end{array}$ & $\begin{array}{l}\text { Pregnancy-associated } \\
\text { maternal } \\
\text { complications }\end{array}$ & $\begin{array}{l}\text { Easy bruising, } \\
\text { ecchymoses }\end{array}$ & $\begin{array}{l}\text { Joint hypermobility } \\
\text { and Beighton score }\end{array}$ & $\begin{array}{l}\text { Valvular disease, } \\
\text { including } \\
\text { mitral valve prolapse } \\
\text { (on Echocardiogram) }\end{array}$ & High-arched palate & $\begin{array}{l}\text { Detachment of } \\
\text { retina }\end{array}$ \\
\hline Ethnic backgrounds & $\begin{array}{l}\text { Uterine rupture/cervical } \\
\text { insufficiency during } \\
\text { pregnancy and delivery }\end{array}$ & $\begin{array}{l}\text { Soft/thin/transparent } \\
\text { skin }\end{array}$ & $\begin{array}{l}\text { Degenerative joint } \\
\text { disease }\end{array}$ & & Single/bifid uvula & $\begin{array}{l}\text { Other vision } \\
\text { abnormalities }\end{array}$ \\
\hline \multirow{6}{*}{$\begin{array}{l}\text { Family history } \\
\text { (focused on joint, } \\
\text { skin, eye, and } \\
\text { vascular abnormalities, } \\
\text { or sudden death) }\end{array}$} & $\begin{array}{l}\text { Delayed motor } \\
\text { development/hypotonia }\end{array}$ & Anal or uterine prolapse & $\begin{array}{l}\text { Chronic joint and } \\
\text { limb pain }\end{array}$ & & $\begin{array}{l}\text { Dysmorphic facial } \\
\text { features }\end{array}$ & Blue sclera \\
\hline & & $\begin{array}{l}\text { Surgical complications } \\
\text { (postoperative hernias, } \\
\text { wound dehiscence) }\end{array}$ & Scoliosis & & $\begin{array}{l}\text { Periodontal disease } \\
\text { and age of onset }\end{array}$ & \\
\hline & & $\begin{array}{l}\text { Spontaneous } \\
\text { pneumothorax }\end{array}$ & Flat feet & & & \\
\hline & & Slow wound healing & Fractures & & & \\
\hline & & Widened, thin scars & & & & \\
\hline & & Stretch marks & & & & \\
\hline
\end{tabular}

\section{RESULTS}

\section{Patients}

Of the 50 patients with spontaneous spinal CSF leaks, 38 were women $(77.6 \%)$ and 12 were men $(22.4 \%)$. The mean age at presentation was 43 years (range, 12-67).

Prevalence of HDCT among patients with spontaneous CSF leaks During the evaluation period, a total of nine patients (all females) were diagnosed with HDCT (18\%). The spectrum of disorders included Marfan syndrome (1 patient), EDS hypermobility type (four patients), EDS classic type (two patients - these presented with milder manifestations of the disease - previously classified as EDS type II, Mitis type (OMIM\# 1300010)) and an unclassified HDCT in two patients. Two out of these nine patients had a preexisting diagnosis (patient \#1 with Ehlers-Danlos syndrome hypermobility type (OMIM\# 130020) and patient \#3 with Marfan syndrome). Patients receiving a diagnosis of a specific connective tissue disorder have met at least the minimal diagnostic criteria according to the published Villefranche classifications, ${ }^{4,5}$ and molecular testing has been completed, when the genetic basis was known. Patients diagnosed with EDS hypermobility type have demonstrated generalized joint hypermobility with joint pain, and mild-skin involvement (mainly soft skin that bruises easily), sometimes in the context of positive family history. Patients diagnosed with the classic type of EDS have demonstrated generalized joint hypermobility, and a more severe skin involvement (mostly hyperextensible skin that bruises easily and widened scars). The diagnosis of an unclassified HDCT in two patients was established, based on generalized skeletal, skin and vascular involvement that did not meet clinical criteria for any of the known HDCT. Overall, the observed spectrum of connective tissue abnormalities included joint laxity and dislocations, skin fragility with easy bruising, abnormal wound healing and spontaneous subcutaneous emphysema, and cardiovascular dysfunction, including arterial dissection, aortic root enlargement and abnormalities of the mitral and tricuspid valves. The clinical findings of these nine patients are summarized in Table 2.

Prevalence of Benign Joint Hypermobility syndrome (BJHM) and isolated features of CTD (ICTD) among patients with spontaneous CSF leaks

Connective tissue signs, not consistent with a definite diagnosis, have been observed in eight patients (16\%). These patients were given a diagnosis of BJHM (OMIM\# 147900), if they demonstrated joint laxity and a family history of joint hypermobility but no skin involvement, or ICTD in patients with mild craniofacial findings but without additional significant skeletal, skin or cardiovascular manifestations or their associated complications suggesting a generalized HDCT (Table 3).

\section{Genetic evaluation}

Gene sequencing of Fibrillin 1 (FBN1), Collagen $5 A 1+2$ $(C O L 5 A 1+2)$, Collagen $3 A 1(C O L 3 A 1)$, and Folliculin C (FLCN) were performed, following establishment of an initial clinical diagnosis in selected patients. FBN1 was sequenced in patient \# 2 to exclude variants of Marfan syndrome that can present with recurrent spontaneous pneumothoraces. ${ }^{10}$ FLCN was sequenced in the same 
Table 2 Clinical findings in patients with CSF leaks and an underlying hereditary disorders of connective tissue

\begin{tabular}{|c|c|c|c|c|c|c|c|c|c|c|}
\hline$\#$ & $\begin{array}{l}\text { Age/ } \\
\text { gender }\end{array}$ & Skin & Skeletal & Eye & CV (Echo) & Craniofacial & Skin histology & Diagnosis & Comments & Genetics \\
\hline 1 & $23 / F$ & $\begin{array}{l}\text { Easy bruising, soft skin, } \\
\text { normal wound healing, } \\
\text { normal scars, no skin } \\
\text { hyperextensibility, } \\
\text { no stretch marks }\end{array}$ & $\begin{array}{l}\text { Normal habitus, } \\
\mathrm{JH}^{a}(5), \text { no } \\
\text { dislocations, no } \\
\text { scoliosis, no joint } \\
\text { pain }\end{array}$ & Myopia & $\begin{array}{l}\text { No MVPb, } \\
\text { normal aorta }\end{array}$ & $\begin{array}{l}\text { Single uvula, } \\
\text { normal palate, } \\
\text { dental } \\
\text { crowding }\end{array}$ & $\begin{array}{l}\text { Normal } \\
\text { collagen and } \\
\text { elastic fibers }\end{array}$ & $\begin{array}{l}\text { Ehlers-Danlso } \\
\text { Syndrome } \\
\text { (EDS)-hyper- } \\
\text { mobility type }\end{array}$ & $\begin{array}{l}\text { Postural ortho- } \\
\text { static tachycar- } \\
\text { dia syndrome }\end{array}$ & None \\
\hline 2 & $35 / F$ & $\begin{array}{l}\text { Soft, transparent skin, } \\
\text { normal wound healing, } \\
\text { normal scars, no skin } \\
\text { hyperextensibility, } \\
\text { no stretch marks, } \\
\text { normal bruising }\end{array}$ & $\begin{array}{l}\text { Normal habitus, } \\
\text { JH (4), no dislo- } \\
\text { cations no } \\
\text { scoliosis, no } \\
\text { joint pain }\end{array}$ & Myopia & $\begin{array}{l}\text { No MVP, } \\
\text { normal aorta }\end{array}$ & $\begin{array}{l}\text { Single uvula, } \\
\text { high-arched } \\
\text { palate, normal } \\
\text { dentition }\end{array}$ & $\begin{array}{l}\text { Normal col- } \\
\text { lagen and } \\
\text { elastic fibers }\end{array}$ & $\begin{array}{l}\text { HDCT- } \\
\text { unclassified }\end{array}$ & $\begin{array}{l}\text { Recurrent (x3) } \\
\text { pneumothoraces }\end{array}$ & $\begin{array}{l}\text { FBN1 } \\
\text { normal, } \\
\text { FLCN } \\
\text { normal }\end{array}$ \\
\hline 3 & $26 / F$ & $\begin{array}{l}\text { Normal wound healing, } \\
\text { normal scars, no skin } \\
\text { hyperextensibility, } \\
\text { multiple stretch marks, } \\
\text { normal bruising }\end{array}$ & $\begin{array}{l}\text { Marfanoid, JH, } \\
\text { scoliosis, joint } \\
\text { pain, no disloca- } \\
\text { tions, pectus } \\
\text { carinatum }\end{array}$ & $\begin{array}{l}\text { Lens } \\
\text { dislocation- } \\
\text { bilateral, } \\
\text { retinal } \\
\text { detachment }\end{array}$ & $\begin{array}{l}\mathrm{S} / \mathrm{P} \\
\mathrm{AVR}^{\mathrm{C}}+\mathrm{MVR}\end{array}$ & $\begin{array}{l}\text { Single uvula, } \\
\text { high-arched } \\
\text { palate, malar } \\
\text { hypoplasia, } \\
\text { retrognathia }\end{array}$ & $\begin{array}{l}\text { Abnormal } \\
\text { collagen fibers }\end{array}$ & $\begin{array}{l}\text { Marfan } \\
\text { Syndrome } \\
\text { (pre-existing } \\
\text { diagnosis) }\end{array}$ & $\begin{array}{l}\text { Dural ectasia at } \\
\text { C7-T1, Arnold- } \\
\text { Chiari } \\
\text { malformation }\end{array}$ & $\begin{array}{l}\text { FBN1 - } \\
\text { known } \\
\text { pathogenic } \\
\text { mutation }\end{array}$ \\
\hline 4 & $31 / F$ & $\begin{array}{l}\text { Soft and hyperextensible } \\
\text { skin, slow wound } \\
\text { healing, widened scars, } \\
\text { no stretch marks }\end{array}$ & $\begin{array}{l}\text { Slender habitus, } \\
\text { JH (4), no dislo- } \\
\text { cations, no scolio- } \\
\text { sis, no joint pain }\end{array}$ & Myopia & $\begin{array}{l}\text { Tricuspid } \\
\text { valve regurgi- } \\
\text { tation, normal } \\
\text { aorta, no MVP }\end{array}$ & $\begin{array}{l}\text { Single uvula, } \\
\text { normal palate } \\
\text { and dentition }\end{array}$ & NA & $\begin{array}{l}\text { EDS Classic } \\
\text { type }\end{array}$ & $\begin{array}{l}\text { Spontaneous } \\
\text { subcutaneous } \\
\text { emphysema }\end{array}$ & $\begin{array}{l}\text { COL5A1+ } \\
\text { COL5A2 } \\
\text { normal }\end{array}$ \\
\hline 5 & $35 / F$ & $\begin{array}{l}\text { Soft, transparent } \\
\text { non-hyperextensible skin, } \\
\text { easy bruising, ecchymoses, } \\
\text { normal wound healing, } \\
\text { normal scars, no stretch } \\
\text { marks }\end{array}$ & $\begin{array}{l}\text { Normal habitus, } \\
\text { small joint JH (4), } \\
\text { no dislocations, no } \\
\text { scoliosis, no joint } \\
\text { pain }\end{array}$ & Myopia & $\begin{array}{l}\text { No MVP, } \\
\text { normal aorta }\end{array}$ & $\begin{array}{l}\text { Single uvula, } \\
\text { normal palate } \\
\text { and dentition }\end{array}$ & $\begin{array}{l}\text { Abnormal col- } \\
\text { lagen fibers }\end{array}$ & $\begin{array}{l}\text { HDCT- } \\
\text { unclassified }\end{array}$ & $\begin{array}{l}\text { Spontaneous } \\
\text { vertebral artery } \\
\text { dissection } \\
\text { Dura biopsy: } \\
\text { Abnormal col- } \\
\text { lagen and elas- } \\
\text { tic fibers }\end{array}$ & $\begin{array}{l}\text { COL5A1+ } \\
\text { COL5A2 } \\
\text { COL3A1 } \\
\text { normal }\end{array}$ \\
\hline 6 & $22 / F$ & $\begin{array}{l}\text { Soft, non-hyperextensible } \\
\text { skin, easy bruising, } \\
\text { ecchymoses, slow wound } \\
\text { healing, normal scars, } \\
\text { no stretch marks }\end{array}$ & $\begin{array}{l}\text { Normal habitus, } \\
\text { JH (5), no dislo- } \\
\text { cations, no } \\
\text { scoliosis, chronic } \\
\text { joint pain }\end{array}$ & $\begin{array}{l}\text { Normal } \\
\text { vision }\end{array}$ & $\begin{array}{l}\text { No MVP, } \\
\text { normal aorta }\end{array}$ & $\begin{array}{l}\text { Single uvula, } \\
\text { normal palate } \\
\text { and dentition }\end{array}$ & $\begin{array}{l}\text { Normal col- } \\
\text { lagen and } \\
\text { elastic fibers }\end{array}$ & $\begin{array}{l}\text { EDS hyper- } \\
\text { mobility type }\end{array}$ & $\begin{array}{l}\text { Dura biopsy: } \\
\text { normal }\end{array}$ & None \\
\hline 7 & $28 / F$ & $\begin{array}{l}\text { Soft, mildly hyperextensible } \\
\text { skin, normal } \\
\text { bruising, normal wound } \\
\text { healing, normal scars, } \\
\text { no stretch marks }\end{array}$ & $\begin{array}{l}\text { Normal habitus, } \\
\text { JH (9), no dislo- } \\
\text { cations, scoliosis, } \\
\text { joint pain }\end{array}$ & Myopia & $\begin{array}{l}\text { No MVP, } \\
\text { normal aorta }\end{array}$ & $\begin{array}{l}\text { Single uvula, } \\
\text { normal palate } \\
\text { and dentition }\end{array}$ & NA & $\begin{array}{l}\text { EDS hyper- } \\
\text { mobility type }\end{array}$ & & None \\
\hline 8 & $23 / F$ & $\begin{array}{l}\text { Soft, hyperextensible skin, } \\
\text { normal bruising, slow } \\
\text { wound healing, abnormal } \\
\text { widened scars, no stretch } \\
\text { marks }\end{array}$ & $\begin{array}{l}\text { Normal habitus, } \\
\text { JH (6), disloca- } \\
\text { tions, no scoliosis, } \\
\text { no joint pain }\end{array}$ & $\begin{array}{l}\text { Normal } \\
\text { vision }\end{array}$ & $\begin{array}{l}\text { No MVP, } \\
\text { normal aorta }\end{array}$ & $\begin{array}{l}\text { Single uvula, } \\
\text { normal palate, } \\
\text { dental } \\
\text { crowding }\end{array}$ & $\begin{array}{l}\text { Abnormalities } \\
\text { in collagen } \\
\text { bundling/ } \\
\text { compaction }\end{array}$ & $\begin{array}{l}\text { EDS Classic } \\
\text { type }\end{array}$ & & $\begin{array}{l}\text { COL5A1+ } \\
\text { COL5A2 } \\
\text { normal }\end{array}$ \\
\hline 9 & $30 / F$ & $\begin{array}{l}\text { Soft, non-hyperextensible } \\
\text { skin, easy bruising, } \\
\text { ecchymoses slow wound } \\
\text { healing, normal scars }\end{array}$ & $\begin{array}{l}\text { Normal habitus, } \\
\text { JH (5), shoulder } \\
\text { dislocation, } \\
\text { chronic joint pain }\end{array}$ & $\begin{array}{l}\text { Normal } \\
\text { vision }\end{array}$ & $\begin{array}{l}\text { No MVP, } \\
\text { normal aorta }\end{array}$ & $\begin{array}{l}\text { Single uvula, } \\
\text { normal palate } \\
\text { and dentition }\end{array}$ & NA & $\begin{array}{l}\text { EDS hyper- } \\
\text { mobility type } \\
\text { (pre-existing } \\
\text { diagnosis) }\end{array}$ & $\begin{array}{l}\text { Family history of } \\
\text { EDS hypermobi- } \\
\text { lity type }\end{array}$ & none \\
\hline
\end{tabular}

a JH - joint hypermobility (according to Beighton score 1-9). ${ }^{4}$

${ }^{\mathrm{b}} \mathrm{MVP}$ - mitral valve prolapse.

${ }^{\mathrm{C} A V R / M V R ~-~ a o r t i c / m i t r a l ~ v a l v e ~ r e p l a c e m e n t . ~}$

Abbreviations: FBN1, fibrillin1; FCNC, folliculinc; COL3/5, collagen 3/5.

patient as mutations in this gene have been reported in some patients with recurrent spontaneous pneumothoraces. ${ }^{11-14}$ Owing to a history of spontaneous vertebral artery dissection in addition to skin and musculoskeletal findings in patient \#5, COL3A1 as well as COL5A $1+2$ were sequenced to exclude the vascular type of EhlersDanlos syndrome and a potential vascular involvement in the classic type of Ehlers-Danlos syndrome, respectively. ${ }^{4,15}$ Both COL5A1 and COL5A2 were normal in patients \# 4 and 8 who were diagnosed with classic EDS ( $<50 \%$ of patients with classic EDS have an identifiable mutation in this gene). The diagnosis of hypermobility EDS is established clinically and the genetic basis is unknown with the exception of very rare TNXB mutations in a small subset of patients. 
Table 3 Clinical findings in patients with CSF leaks and Familial Benign Joint Hypermobility syndrome or isolated features of CTD

\begin{tabular}{|c|c|c|c|c|c|c|c|c|}
\hline \# & Age/gender & Skin & Skeletal & Eye & Cardiovascular & Craniofacial & $\begin{array}{l}\text { Skin } \\
\text { biopsy }\end{array}$ & Comments \\
\hline 1 & $59 / F$ & Easy bruising & Slender habitus, scoliosis & Myopia & Aortic root $40 \mathrm{~mm}$, no MVP & Dental crowding & Normal & \\
\hline 2 & $66 / F$ & None & Normal habitus, JH (5) & Myopia & No MVP, normal aortic root & None & Normal & $\begin{array}{l}\text { Dura biopsy: } \\
\text { normal }\end{array}$ \\
\hline 3 & $52 / F$ & Easy bruising & Normal habitus, JH (4) & Myopia & No MVP, normal aortic root & None & Normal & $\begin{array}{l}\text { Family history } \\
\text { of } \mathrm{JH}\end{array}$ \\
\hline 4 & $63 / M$ & None & Pectus carinatum & Normal vision & Normal aortic root, no MVP & High-arched palate & NA & \\
\hline 5 & $46 / F$ & None & Normal habitus, JH (4) & Myopia & $\mathrm{N} / \mathrm{A}$ & High-arched palate & NA & \\
\hline 6 & $18 / \mathrm{M}$ & None & Normal habitus, JH (7) & Normal vision & No MVP, normal aortic root & Dental crowding & Normal & $\begin{array}{l}\text { Family history } \\
\text { of } \mathrm{JH}\end{array}$ \\
\hline 7 & $46 / F$ & None & Normal habitus, JH (5), & Normal vision & $\mathrm{N} / \mathrm{A}$ & High-arched palate & NA & $\begin{array}{l}\text { Family history } \\
\text { of } \mathrm{JH}\end{array}$ \\
\hline 8 & $49 / F$ & $\begin{array}{l}\text { Soft skin, } \\
\text { easy bruising }\end{array}$ & $\begin{array}{l}\text { Slender habitus, no JH, } \\
\text { patellar dislocation }\end{array}$ & Myopia & No MVP, normal aortic root & $\begin{array}{l}\text { High-arched palate, } \\
\text { dental crowding }\end{array}$ & Normal & \\
\hline
\end{tabular}

Therefore, genetic testing has not been further pursued in patients 1 , 6,7 , and 9 .

\section{Skin histopathology}

Electron microscopy examination of skin biopsies from 28 patients and dura biopsies from 7 patients revealed inconsistent findings with five samples ( 3 patients with HDCT and 2 with spontaneous CSF leaks but no connective tissue abnormalities) demonstrating significant pathological changes in the distribution, diameter and striation pattern of collagen and elastic fibers. All others appeared normal with minimally, non-specific changes. These results essentially exclude skin histopathology as being an efficient clinical tool to support a diagnosis of spontaneous CSF leak in patients with an underlying HDCT.

\section{DISCUSSION}

The main finding of our study was the high frequency of connective tissue abnormalities in patients with spontaneous CSF leaks. In addition, the spectrum of connective tissue abnormalities was broader than previously described, and ranges from rather benign hypermobility syndrome to life-threatening disorders with variable combinations of vascular, cardiac, skin and joint-related symptoms and signs. This may dictate future surveillance and management guidelines for those patients. Overall, we found that the neurological presentation, the findings on imaging studies, and the histopathological findings, cannot distinguish between patients with and without an underlying HDCT. An additional observation in this cohort is that the immediate outcome (ie, resolution of symptoms assessed following surgical procedure and before discharge) seems to be similar among patients with and without an underlying HDCT. Thus, until a long-term follow-up on this cohort will be available, the same management protocol should generally be applied to both groups. This protocol includes several modalities such as an epidural blood patch, followed by a percutaneous placement of fibrin glue or surgical repair of the leak in more resistant, recurrent cases.

The prevalence of HDCT in patient with spontaneous CSF leaks has been rarely estimated. Most reported studies described either single or limited number of patients, thus increasing the risk of publication bias. ${ }^{6-9}$ A review of the medical records of 58 patients with spontaneous CSF leaks found nine patients (seven females and two males) who exhibited some clinical features of a connective tissue disorder. ${ }^{16}$ The limitations of this study are that detailed descriptions of the patients and methods of evaluation are not available.

A recent prospective study has attempted to overcome these limitations by enrolling a cohort of consecutive Taiwanese patients presented with spontaneous CSF leaks and matched controls that were evaluated for connective tissue signs of Marfan syndrome and the hypermobility type of Ehlers-Danlos syndrome. ${ }^{7}$ None of the patients in this cohort received a diagnosis of a HDCT, while there was a tendency toward a high frequency of skin findings in both groups. Yet, this study was limited by several factors. First, the clinical evaluation protocol was not strict enough to include the key features on medical history and clinical examination that can be associated with HDCT, possibly biasing the reported incidence. Second, the authors focused on the rather peripheral skeletal findings associated with Marfan syndrome, but overlooked other important manifestations, including the major diagnostic criteria (family history, lens dislocation, aortic dilatation) that were defined in the revised nosology, which might have produced false-negative results of Marfan syndrome. Third, ancillary studies such as echocardiograms and genetic studies were not included; these studies are sometimes key in the diagnosis of several HDCT.

The recognition of HDCT in patients with spontaneous CSF leaks may be important mainly because of the potential vascular (and other connective tissue) fragility that is associated with them. Although limited by the size of this cohort, it would appear that the data shown here present a case for screening individuals with spontaneous CSF leaks for connective tissue and vascular complications.

Descriptions of patients with connective tissue disorders do not report an association with spontaneous CSF leaks, suggesting that it is not a common complication of this group of disorders. ${ }^{17}$ However, the precise incidence of which is unknown, as headache is a common complaint among patients with HDCT, and only a minority of affected individuals have undergone appropriate examination.

The recognized HDCT that we diagnosed in this cohort are two subtypes of EDS and Marfan syndrome. The hypermobility type of EDS is the most common subtype of EDS and a common cause of chronic, undiagnosed pain syndrome. Clinical manifestations include painful and chronic joint instability and dislocations leading to degenerative joint disease at a young age. ${ }^{18}$ The genetic basis of EDS hypermobility type is unknown in most cases; therefore, the diagnosis of this type is based entirely on clinical evaluation that 
includes musculoskeletal and skin findings and sometimes positive family history, but the absence of fragility of other soft tissues. ${ }^{4}$ The classic type of EDS is characterized by joint hypermobility, similar to the one observed in the hypermobility type, but a much more extensive skin involvement (skin hyperextensibility, abnormal wound healing and scar formation), as well as fragility of other connective tissues in some cases (large arteries, cervical insufficiency during pregnancy, recurrent hernias, rectal prolapse etc). ${ }^{4,19}$ The diagnosis of EDS classic type is established clinically, although up to $50 \%$ of individuals have a mutation in COL5A1 or COL5A2, the genes encoding type $\mathrm{V}$ collagen. Therefore, a positive genetic testing supports the diagnosis, whereas a negative test cannot rule it out. In addition, although cauliflower deformity of skin collagen fibrils is a characteristic of classic EDS, it is not specific or diagnostic, especially in milder cases, such as the patients described here. The clinical manifestations of Marfan syndrome are highly variable and can involve the ocular, skeletal, skin, cardiovascular, and pulmonary systems. Mutations in FBN1 have been detected in 95\% of affected patient although the diagnosis can usually be established clinically. ${ }^{5,20}$ CSF leaks from dural sac have been reported in Marfan syndrome. ${ }^{21}$

There were several limitations to the current study. First, there is an unequal distribution of gender in this study (38 females vs 12 males). It is not known whether females have a higher incidence of CSF leaks itself, or symptoms arising from it, or whether this is due to sampling bias. As HDCT, and especially EDS hypermobility type, are more prevalent in symptomatic females, ${ }^{22}$ this gender bias must be taken into account when trying to generalize the sample data to the general group of patients with CSF leaks. Second, selection bias should be considered in this study. As all the recruited patients were referred, they might have a different disease spectrum, because many patients with spontaneous CSF leaks recover spontaneously without seeking a referral. Therefore, the study results cannot be generalized to all patients with spontaneous CSF leaks. Future studies including longterm follow-up on this cohort are needed to understand the impact of an underlying HDCT on the natural history and management of patients with spontaneous CSF leaks.

In conclusion, although clinicians need to be aware of the cardiac, vascular and connective tissue manifestations associated with HDCT, the association of spontaneous CSF leaks with these abnormalities may be an additional clinical manifestation in the spectrum of generalized connective tissue fragility. We propose that there is a clinical basis for considering spontaneous CSF leak as a clinical manifestation of HDCT, and that individuals with spontaneous CSF leaks should be evaluated for connective tissue and vascular abnormalities.

\section{CONFLICT OF INTEREST}

The authors declare no conflict of interest.

\section{ACKNOWLEDGEMENTS}

Dr Rimoin appreciated support from the Steven Spielberg Pediatric Research Center, the NIH/NICHD Program Project Grant (HD36657), the Medical Genetics NIH/NIGMS Training Program Grant (5-T32-GM08243), and the Cedars-Sinai General Clinical Research Center Grant (M01-RR00425) for samples collected under CSMC IRB Protocols 0463 and 4232.

1 Schievink WI, Dodick DW, Mokri B, Silberstein S, Bousser MG, Goadsby PJ: Diagnostic criteria for headache due to spontaneous intracranial hypotension: a perspective. Headache 2011; 51: 1442-1444.

2 Schievink WI: Spontaneous spinal cerebrospinal fluid leaks and intracranial hypotension. JAMA 2006; 295: 2286-2296

3 Byers PH, Schwarze U: Ehlers-Danlos syndrome; In: Rimoin DL, Connor JM, Pyeritz $\mathrm{RE}$, Korf BR eds. Emery and Rimoin's Principles and Practice of Medical Genetics, 5th edn New YorkChurchill-Livingstone: Elsevier, 2007; 3625-3646.

4 Beighton P, De Paepe A, Steinmann B, Tsipouras P, Wenstrup RJ: Ehlers-danlos syndromes: revised nosology, villefranche, 1997. Am J Med Genet 1998; 77: 31-37.

5 Loeys BL, Dietz HC, Braverman AC et al: The revised Ghent nosology for the Marfan syndrome. J Med Genet 2010; 47: 476-485.

6 Schievink WI, Reimer R, Folger WN: Surgical treatment of spontaneous intracranial hypotension associated with a spinal arachnoid diverticulum. Case report. J Neurosurg 1994: 80: 736-739.

7 Liu FC, Fuh JL, Wang YF, Wang SJ: Connective tissue disorders in patients with spontaneous intracranial hypotension. Cephalalgia 2011; 3: 691-695.

8 Schrijver I, Schievink WI, Godfrey M, Meyer FB, Francke U: Spontaneous spinal cerebrospinal fluid leaks and minor skeletal features of Marfan syndrome: a microfibrillopathy. J Neurosurg 2002; 96: 483-489.

9 Schievink WI, Gordon OK, Tourje J: Connective tissue disorders with spontaneous spinal cerebrospinal fluid leaks and intracranial hypotension: a prospective study. Neurosurgery 2004; 54: 65-70.

10 Cardy CM, Maskell NA, Handford PA et al: Familial spontaneous pneumothorax and FBN1 mutations. Am J Respir Crit Care Med 2004; 169: 1260-1262.

11 Painter JN, Tapanainen H, Somer M, Tukiainen P, Aittomäki K: A 4-bp deletion in the Birt-Hogg-Dube gene (FLCN) causes dominantly inherited spontaneous pneumothorax. Am J Hum Genet 2005; 76: 522-527.

12 Ren HZ, Zhu CC, Yang C et al: Mutation analysis of the FLCN gene in Chinese patients with sporadic and familial isolated primary spontaneous pneumothorax. Clin Genet 2008; 74: 178-183.

13 Gunji Y, Akiyoshi T, Sato T et al: Mutations of the Birt-Hogg-Dube gene in patients with multiple lung cysts and recurrent pneumothorax. J Med Genet 2007; 44 588-593.

14 Kunogi M, Kurihara M, Ikegami TS et al: Clinical and genetic spectrum of Birt-HoggDube syndrome patients in whom pneumothorax and/or multiple lung cysts are the presenting feature. J Med Genet 2010; 47: 281-287.

15 Borck G, Beighton P, Wilhelm C, Kohlhase J, Kubisch C: Arterial rupture in classic Ehlers Danlos syndrome with COL5A1 mutation. Am J Med Genet A 2010; 152: 2090-2093.

16 Mokri B, Maher CO, Sencakova D, Spontanous CSF: leaks: underlying disorders of connective tissue. Neurology 2002; 58: 814-816.

17 Grosveld WJ, Gilhuis HJ, Voermans NC: Spontaneous intracranial hypotension in a patient with classical type Ehlers-Danlos syndrome. Neurol India 2011; 59: 633-634.

18 Castori M, Camerota F, Celletti C, Grammatico P, Padua L: Natural history and manifestations of the hypermobility type Ehlers-Danlos syndrome: a pilot study on 21 patients. Am J Med Genet A 2010; 152: 556-564.

19 Malfait F, Wenstrup RJ, De Paepe A: Clinical and genetic aspects of Ehlers-Danlos syndrome, classic type. Genet Med 2010; 12: 597-605.

20 Dietz HC: Marfan syndrome; In: Pagon RA, Bird TD, Dolan CR, Stephens K eds. GeneReviews [Internet]. Seattle (WA): University of Washington, 1993.

21 Foran JR, Pyeritz RE, Dietz HC, Sponseller PD: Characterization of the symptoms associated with dural ectasia in the Marfan patient. Am J Med Genet A 2005; 134: $58-65$

22 Castori M, Camerota F, Celletti C, Grammatico P, Padua L: Ehlers-Danlos syndrome hypermobility type and the excess of affected females: possible mechanisms and perspectives. Am J Med Genet A 2010; 152: 2406-2408. 